\title{
The Governors of Halzi-atbari in the Neo-Assyrian Period
}

\author{
Luukko, Mikko
}

Eisenbrauns

2017

Luukko, M 2017 , The Governors of Halzi-atbari in the Neo-Assyrian Period . in Y Heffron, A Stone \& M Worthington (eds), At the Dawn of History : Ancient Near Eastern Studies in Honour of J. N. Postgate . vol. 1 , Eisenbrauns , Winona Lake, IN , pp. 321-333 .

http://hdl.handle.net/10138/310688

unspecified

publishedVersion

Downloaded from Helda, University of Helsinki institutional repository.

This is an electronic reprint of the original article.

This reprint may differ from the original in pagination and typographic detail.

Please cite the original version. 


\section{At the Dawn of History}

\section{Ancient Near Eastern Studies in Honour of J. N. Postgate}

edited by

YaĞmur Heffron, Adam Stone, and Martin Worthington

Winona Lake, Indiana

EISENBRAUNS 
Copyright @ 2017 Eisenbrauns Inc.

All rights reserved.

Printed in the United States of America.

www.eisenbrauns.com

\section{Library of Congress Cataloging-in-Publication Data}

Names: Heffron, Yağmur, editor. | Stone, Adam, 1981- editor. | Worthington, Martin, editor. | Postgate, J. N., honoree.

Title: At the Dawn of History : Ancient Near Eastern Studies in Honour of J.N. Postgate / edited by Yağmur Heffron, Adam Stone, and Martin Worthington.

Description: Winona Lake, Indiana : Eisenbrauns, 2017. | Includes bibliographical references. I Description based on print version record and CIP data provided by publisher; resource not viewed.

Identifiers: LCCN 2016049835 (print) | LCCN 2016049136 (ebook) | ISBN 9781575064741 (ePDF 2-volume set) | ISBN 9781575064710 (cloth, set 2 volumes : alk. paper) | ISBN 9781575064727 (volume 1 : alk. paper) | ISBN 9781575064734 (volume 2 : alk. paper)

Subjects: LCSH: Iraq-Civilization-To 634. | Iraq-History-To 634. | IraqAntiquities. | Civilization, Assyro-Babylonian. | Akkadian language-Texts. Classification: LCC DS69.5 (print) | LCC DS69.5 .A86 2017 (ebook) | DDC 935-dc23

LC record available at https://lccn.loc.gov/2016049835

The paper used in this publication meets the minimum requirements of the American National Standard for Information Sciences-Permanence of Paper for Printed Library Materials, ANSI Z39.48-1984.@TM 


\section{Contents}

\section{Volume 1}

Editors'Preface ....................... . . ix

Nicholas Postgate's Publications $\ldots \ldots \ldots$. . . . . . . . . xiii

A Fragment of a Stele from Umma . . . . . . . . . . . . . . . . . 1

Lamia Al-Gailani Werr

In the Shade of the Assyrian Orchards . . . . . . . . . . . . . . . . 7

Marie-Françoise Besnier

The Šu-Suen Year $9 \mathrm{sa}_{2}-\mathrm{du}_{11} \mathrm{ku}_{5}-\mathrm{ra}_{2}$ Flour Dossier from Puzriš-Dagan . . . . . . . 25 ROBERT BigGs

To Eat Like a God: Religion and Economy in Old Babylonian Nippur . . . . . 43 Nicole BRISCH

Remarks on the Earliest History of Horoscopy . . . . . . . . . . . . . . . 55 DAVID BROWN

A Ceramic Assemblage of the Early Literate Periods from Sumer . . . . . . . . 73 Daniel Calderbank and Jane Moon

Stolen, Not Given? ． . . . . . . . . . . . . . . . . . . . 85 María Dolores Casero Chamorro

Are We Any Closer to Establishing How Many Sumerians per Hectare?

Recent Approaches to Understanding the Spatial Dynamics of

Populations in Ancient Mesopotamian Cities . . . . . . . . . . . . 95 Carlo Colantoni

New Perspectives on 'Early Mesopotamia' _ . . . . . . . . . . . . . . . . . . 119 Harriet Crawford

Of Arches, Vaults and Domes . . . . . . . . . . . . . . . . . 127 Stephanie Dalley

Ethnicity in the Assyrian Empire: A View from the Nisbe, (III)

"Arameans" and Related Tribalists . . . . . . . . . . . . . . . . . . 133 Frederick Mario FaLes 
Instruktionen Tukultì-Ninurtas I. . . . . . . . . . . . . . . . . . . . . . . 179 HeLmut Freydank

Gods, Temples, and Cult at the Service of the Early Hittite State . . . . . . . 189 Marie-Henriette Gates

The Ending of the Çineköy Inscription . . . . . . . . . . . . . . . 211

David Hawkins

A New Palatial Ware or a Case of Imitation of Egyptian Pottery?

The Brownish Red Slip (BRS) from Qatna and Its Significance within the Northern Levantine Ceramic Tradition of the Mid-Second Millennium BC . . . . . . . . . . . . . . . . 217 Marco IAMONI

Building on the Past: Gertrude Bell and the Transformation of Space in the Karadağ . . . . . . . . . . . . . . . . . . . . . . . 239 MARK JACKSON

Studies in the Lexicon of Neo-Aramaic . . . . . . . . . . . . . . . . . . . 255 GeOFFrey Khan

The Temple of Salmānu at Dūr-Katlimmu, Nergal of Hubšalum, and Nergal-ereš . . . . . . . . . . . . . . . . . . . 271 HARTMUT KüHNE

Between Slavery and Freedom ． . . . . . . . . . . . . . . . . . . . . 289 Mogens Trolle Larsen

The King and His Army . . . . . . . . . . . . . . . . . . . . . . 301 Mario Liverani

Two Middle Assyrian Delivery Notes from the British Museum's

Tablet Collection . . . . . . . . . . . . . . . . . . . 313

Jeanette C. Fincke and Jaume Llop-Raduà

The Governors of Halzi-atbari in the Neo-Assyrian Period . . . . . . . . . . . . 321 Мiкко Luukкo

Never The Same River Twice: The Göksu Valley Through the Ages . . . . . . . . 335

Naoíse Mac Sweeney and Tevfik Emre ŞerifoĞLu

Piecing the Jigsaw . . . . . . . . . . . . . . . . . . . . . 355

Harriet Martin

A Palace for the King of Ereš? Evidence from the Early Dynastic City of Abu Salabikh, South Iraq . . . . . . . . . . . . . . . 363 Roger Matthews and Wendy Matthews 
How Many Sumerians Does It Take to Put Out the Rubbish? . . . . . . . . 373 Augusta McMahon

\section{Volume 2}

The Location of Rasappa . . . . . . . . . . . . . . . . . . . . . . 393 Simo PARPOLA

Making Fire in Uruk-Period Abu Salabikh . . . . . . . . . . . . . . . 413 Susan Pollock

A Neo-Assyrian Legal Document from Tell Sitak . . . . . . . . . . . . . . . . . 423 KAREN RADNER

The Assyrian Palace at Nabi Yunus, Nineveh . . . . . . . . . . . . . . 431 Julian ReAde

The Socio-Economics of Cuneiform Scholarship after the 'End of Archives':

Views from Borsippa and Uruk . . . . . . . . . . . . . . . . . . 459 ELEANOR ROBSON

Eine Königskette im Heiligtum der Ištar von Assur . . . . . . . . . . . . . . . . 475 Ursula Seidl

On the Tablet Trail: Herdsmen's Employment for

Royal Wives in the Ur III Period . . . . . . . . . . . . . . . . . . . . 481 T. M. SHARLACH

An Expedition of King Shalmaneser I and Prince Tukultī-Ninurta

to Carchemish . . . . . . . . . . . . . . . . . . . 491 Daisuke Shibata

The Role of Stimulants in Early Near Eastern Society:

Insights through Artifacts and Texts . . . . . . . . . . . . . 507 DiAna STEIN

An Estimate of the Population of the City of Umma in Ur III Times . . . . . . . 535 Piotr Steinkeller

How Many Mesopotamians per Hectare? . . . . . . . . . . . . . . . . . . . . . . 567 Elizabeth C. Stone

The Terminology for Times of the Day in Akkadian . . . . . . . . . . . 583 Michael P. Streck

'Counter-Archaeology': Putting the Ur III Drehem Archives

Back in the Ground . . . . . . . . . . . . . . . . . . 611 Christina Tsouparopoulou 
Meaning in Perspective: Some Akkadian Terms for 'Foundation'-uššu, temennu, išdu, duruššu . . . . . . . . . . . . . . . . . . . . . . 631 Johanna Tudeau

Nergal-etiris's Correspondence in the Light of BM 30205, and a Preliminary Edition of BM 36543, another Fragmentary

Neo-Assyrian Letter in the Babylon Collection of the British Museum . . . 651 Greta Van Buylaere

Seven Debt-Notes of Anatolians from Ancient Kanesh ～. . . . . . . . . . . . 665 KlaAs R. VeENHOF

Oracle Bones at the Sichuan University Museum . . . . . . . . . . . . . . 685 Xianhua Wang and Changhong Chen

Association of the Dog with Healing Power in Mesopotamia . . . . . . . . . 689 Chikako E. Watanabe

Ugaritic Military Terms in the Light of Comparative Linguistics . . . . . . . . . . 699 WiLfRED G. E. WATSON

Tabal and the Limits of Assyrian Imperialism . . . . . . . . . . . . . 721 MARK WEEDEN

Ein dritter Backstein mit der großen Inschrift des Königs Takil-ilissu von Malgûm und der Tonnagel des Ipiq-Ištar . . . . . . . . . . . . . . 737 Claus Wilcke

Assur among the Gods of Urartu . . . . . . . . . . . . . . . . . 753 PAUl Zimansky

Some Bronze Stamp Seals of Achaemenid Date . . . . . . . . . . . . . 765 DominiQue Collon and John CuRtis

Assyrians after the Fall: Evidence from the Ebabbar of Sippar . . . . . . . . . . . 781 John MaCGinnis

Prayer and Praise in the City of Assur . . . . . . . . . . . . . . . 797 Frances ReynOldS

Owing to circumstances for which the editors assume full responsibility, and for which neither authors nor publisher are to blame, the contributions by Dominique Collon and John Curtis, John MacGinnis, and Frances Reynolds were not included in the materials originally submitted to the publisher. As a result, they appear at the end of volume 2 instead of at the appropriate alphabetical location in the publication. 


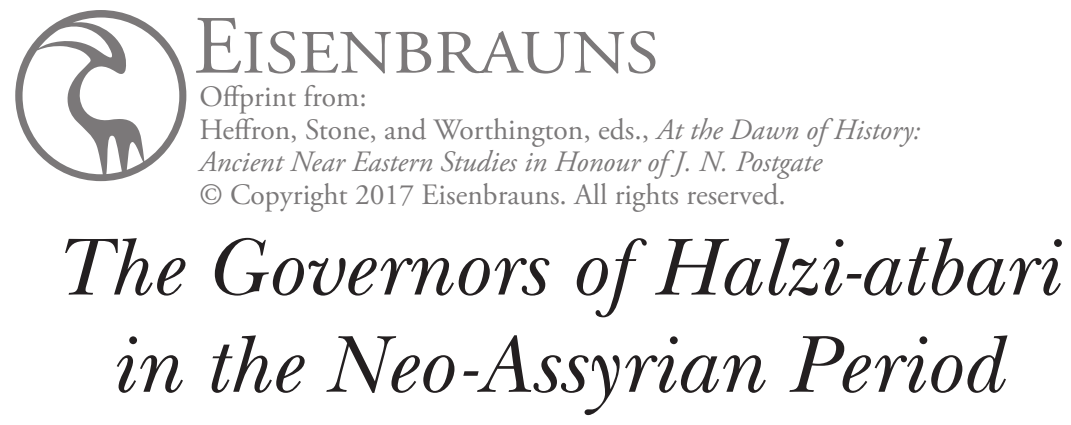

\author{
Mikko LuUkko
}

According to Tiglath-pileser III's Mila Mergi Rock Relief Inscription, Halzi-atbari was a "rebellious land" during his early reign. ${ }^{1}$ Consequently, in his seventh regnal year (739), Halziatbari was annexed to Assyria when Tiglath-pileser III conquered Ulluba ${ }^{2}$ and placed one of his eunuchs as provincial governor over the people of that land. ${ }^{3}$ This episode does not exclude the possibility that the region of Halzi-atbari may have already belonged to Assyria at an earlier date, in particular because of the unclear definition "rebellious land" (mätu nabalkuttu), even if there are no mentions of the toponym before Tiglath-pileser's reign.

Halzi-atbari is one of the lesser-known provinces of the Assyrian empire. ${ }^{4}$ As with many other Assyrian provinces, its exact location is uncertain and still disputed today. Current views on its location may be summarized as follows: Postgate locates it to the west of central Assyria: "Given that adbaru stone seems to be volcanic, it is tempting then to seek this province in the area SW of Jebel Sinjar, which had a long-standing association with basalt, especially the alveolar pumice used for grindstones. It could well have been created in the later 8th century from part of the province of Rașappa which had remained so unusually big." ${ }^{5}$ Parpola and Porter, on the other hand, situate the province to the north-east of Tillê, south of Šabirešu and south-west of Aššr-iqiša, about $100 \mathrm{~km}$ north-west of Nineveh. ${ }^{6}$ In spite of these dissenting opinions on the location of the province, there probably is consensus that we should look for it in a moun-

Author's note: The preparation of this article was facilitated by the access to the database of the NeoAssyrian Text Corpus Project (Helsinki). I would like to thank Jamie Novotny and Greta Van Buylaere for reading a draft of this manuscript. For the abbreviations used in this article, see M. P. Streck (ed.), Reallexikon der Assyriologie, volume 13/7-8 (Berlin / New York 2013), III-LXV. In addition, NL = Saggs, The Nimrud Letters (Iraq 17 [1955], etc.) and QGS = Quaderni di Geografica Storica.

1. The inscription was first edited by Postgate in 1973b, including an excellent copy of the inscription as Fig. 1. The latest edition can be found in RINAP 1, no. 37. Apart from the end of line 23, the readings of the signs in the line are certain. Tadmor 1994: 114-15, in his edition of Tiglath-pileser's royal inscriptions, translates it as follows: "[To Hal]ziatbar, the rebellious land [. . .]".

2. "It is probably significant that it was the abarakku [= masennu "treasurer"] Sin-taklak who in 739 B.C. led a campaign against Ulluba. Ulluba is known from the Mila Mergi inscription to be in the valley of the Lesser Habur, north of [modern] Dohuk" (Postgate 1995: 7). On the geographical situation of the Mila Mergi inscription, see id. 1973b: 48-49, Fig. 2 (historical geography in ibid. pp. 57-59). On Tiglathpileser's campaign against Ulluba, see also Parker 2001: 52-55.

3. The passage is broken, but see RINAP 1, no. 37: 44.

4. The name can also be read as Halzi-adbari. About twenty attestations of the province are known to me, but many of them are not helpful with regard to its location.

5. Postgate 1995: 12. For example, Radner 2006: 54 and Faist 2007: 117, note to line 46, follow Postgate's proposed location for Halzi-atbari.

6. Parpola and Porter 2001: map 4 B4, see also p. 9 of the Gazetteer. 
tainous area or at least at the foot of a mountain that may not have been situated very far from central Assyria. ${ }^{7}$ At the end of the article, I will return to this question and briefly consider some evidence pertaining to the location of the province of Halzi-atbari.

Etymologically, the name Halzi-atbari is the sum of two elements forming a compound word that can be understood in the sense of "Basalt district" or "Fortress of basalt". The word halzu ${ }^{8}$ means both "fortress" and "district", and atbāru is the word for "basalt" ${ }^{\text {. The name may }}$ have been coined in the early Neo-Assyrian period, or perhaps earlier, and it may have been used until the end of Assyrian hegemony in the area, or possibly even longer. The fact that there are no extant attestations of Halzi-atbari before the reign of Tiglath-pileser III might suggest that the province and its name were created late, in the second half of the eighth century.

There may be some practical reasoning behind the choice of the name Halzi-atbari. For example, in the letter $S A A 158$, whose geographical origin is uncertain, the chief treasurer Ṭab-šar-Aššur writes to the king that he is completing his mission of cutting 150 basalt slabs and transporting them to Nineveh. If the letter relates to Halzi-atbari, then the province may have had a proper quarry to procure that desired stone. ${ }^{10}$ The cut slabs were presumably meant for the bathroom of the Aššur temple. Since the letter does not provide any information about the source of the stone, ${ }^{11}$ any connection between the letter and the province of Halzi-atbari must remain conjectural, but one could speculate that the basalt was quarried in the province of the treasurer in the north. ${ }^{12}$ On the other hand, had alabaster been abundantly available in the region, then the question of a quarry would be superfluous.

In addition to the chief treasurer Țab-šar-Aššur, ${ }^{13}$ Ṭab-ṣill-Ešarra, governor of Assur and eponym of the year $716,{ }^{14}$ was another official who played a major role in coordinating construction projects at Dur-Šarruken, Sargon's capital-to-be. Interestingly, in one of his letters the

7. Halzi-atbari is mentioned in connection with central Assyrian provinces in at least two texts: CTN 3 86: 15-17 (followed by Tamnuna, Talmusa and Isana) and SAA 11 7: 2'-6' (preceded by Kurbail and followed by Tamnuna and Talmusa). It may also be meaningful that the eponymate of Šulmu-šarri (year 698), governor of Halzi-atbari (see below), is sandwiched between those of the governors of Kurbail and Tamnuna. In the Mesopotamian anti-witchcraft rituals, the atbāru-stone symbolizes purity (see Abusch and Schwemer 2011, texts 7.5, 1.: 3', 7'; 7.6.4: 27'; 7.8, 7.: 19', 23'; 7.10, 1.: 188'"'; 8.5, 1.: 8'; 9.2: 15; 9.3: $10^{\prime}, 12^{\prime}, 23^{\prime}$ ), as suggested by the fact that "the atbarru-stone ("basalt") bears the epithet 'pure mountain' in the incantations referring to the rite of standing on basalt when addressing the sun-god" (Abusch and Schwemer 2011: 397, note to lines 23'-24').

8. CDA 103a (halsu II), AHw 313-14 (halș II) and CAD H s.v. halsu.

9. $C D A$ 30b, $A H w$ 86b ("etwa 'Basaltlava'") and CAD A/2 s.v. atbaru. For the name, see Postgate 1995: 1, 12.

10. For the building projects supervised by the chief treasurer, see Mattila 2000: 26-27.

11. See also the discussion of the letter by Reade 2008: 22-23.

12. Another letter (SAA 167 ) written by Țab-šar-Aššur concerns the bathroom of the hilanu palace (see Reade 2008: 30); see also SAA 1 121, whose sender is Aššur-bani, the governor of Kalhu. In general, it is worth noting that the activities of Țab-šar-Aššur mainly take place along a north-south axis, from his province in the north down to the city of Assur in the south. Geographically, an exception may be his letter $S A A 150$, which has something to do with an emblem of the moon god of Harran; only the first eight lines of the letter survive. In fact, this letter may relate to construction at Dur-Šarruken (topically cf. SAA 166 r.5-10).

13. Author/sender of SAA 1 41-74, SAA 5 282-90.

14. Author/sender of SAA 1 75-109, SAA 5291. 
governor of Assur complains to the king that he has not been able to till the king's arable land [in] Halzi-atbari (SAA 1 106: 15-19). Although these lines in the letter are very fragmentarily preserved, they may be understood as conflicting with the positive example set in the Halahhu region (lines 6-14), which is located in central Assyria. ${ }^{15}$

\section{SAA 1968}

We now turn to other textual sources dealing, directly or indirectly, with Halzi-atbari. At first glance the short, but well-preserved, letter $S A A 1968,{ }^{16}$ which is written by an Assyrian official named Šamaš-ila'i, appears insignificant. ${ }^{17}$ In his 2001 edition of the Nimrud Letters, Saggs included this piece of correspondence in his "Wellbeing of the Land" section, which included twelve other letters. ${ }^{18}$ The letter reads: ${ }^{19}$

(1) ana šarri bēlīya / șurdaka Šamašila’i / lū šulmu ana šarri / bēlīya / (5) adanniš / šulmu ina mātīka / šulmu ana nīši / mātīka / Aššur u Šamaš / (10) [a]na šarri // (r.1) bèlìya / likrubu

(1) To the king, my lord: your servant Šamaš-ila’i. The best of health to the king, my lord! (6) Your country (and) the people of your country are well. May Aššur and Šamaš bless the king, my lord!

The letter does not contain more than an address (lines 1-2), greeting (lines 3-5), report of the well-being of a land and its inhabitants (lines 6-8), and a closing blessing (lines 9-r.2). Admittedly, this short letter does not appear very informative, but "no news is good news". ${ }^{20}$ On the other hand, the letter includes some rare and/or interesting features that stand out. In particular, after the first five standardized lines, a striking feature is how the well-being of the country and its people is phrased: šulmu ina mātìka šulmu ana nī̌š mātìka.$^{21}$ Despite the regular use of

15. Despite the KUR determinative, e.g., in $S A A 1$ 106: 7, Halahhu is no longer a province at this time; for a recent discussion of Halahhu, see Radner 2006: 54. The geographical implications of this letter, in particular relating to Halzi-atbari, are not clear to me. See note 7 for sources mentioning this province along with well-known, central Assyrian provinces.

16. ND $2697($ IM 64123) $=$ NL $30=C T N 5$, p. 200.

17. I deliberately refrained from commenting on this letter in $S A A 19$ since I wanted to discuss it more fully elsewhere. I have already suggested identifying Šamaš-ila’i with the governor of Halzi-atbari in my dissertation (Luukko 2004: 234), but without giving any evidence for the rationale behind this assumption.

18. CTN 5, pp. 193-205: ND 2355 (SAA 19 19); ND 2372 (SAA 19 11); ND 2409 (SAA 19 10); ND 2449 (SAA 19 15); ND 2462 (SAA 19 166); ND 2617 (SAA 19 113); ND 2719 (SAA 19 158); ND 2731 (SAA 19 78); ND 2736 (SAA 19 79); ND 2757 (SAA 1 1); ND 2784 (SAA 19 63); ND 2792 (SAA 19 9).

19. Repeated from $S A A 1968$.

20. Had there been recent unrest in the area, then the opposite "all is well" confirms the turbulence has ended, and is valuable news. Also the following letters are without - or with very little - content: $S A A$ 1911 (by the crown prince Ululaya [Shalmaneser V]), SAA 1 173-174 (by Adda-hati), SAA 51 (by NashurBel), SAA 565 (by Na'di-ilu), and SAA 1964 (by Duri-Aššur). With the possible exception of Ululaya's letter, none of the other pieces of correspondence were sent from central Assyria.

21. In the Nimrud Letter corpus, the (ortho)graphic variant $(l \bar{u}) \check{s} u l m u$ ina, which appears in lieu of the frequently attested (lū) šulmu ana, also occurs in SAA 19 14: 5-6 (by Bel-abu'a); 69: 6-7 (sender's 
urdaka $(u r d u+k a)$, "your servant", which appears in the second line of most Neo-Assyrian letters and refers to the Assyrian king, the possessive suffix - $k a$ "your" attached to "country/ land" in lines 6 and 8 is so far not attested in a comparable passage (i.e., in a report section between a greeting and a blessing) in any other Neo-Assyrian letter from a subordinate to a superior. Here the expected phrase is the comparable and frequently attested šulmu ana mäti ša šarri, "the land of the king is well". ${ }^{22}$ The expression "people of the land/country" is also attested in other Neo-Assyrian and Neo-Babylonian letters to the king of Assyria. ${ }^{23}$

To find a parallel for "your $(-k a)$ country/land" in a Neo-Assyrian letter addressed to an Assyrian king, we have to go so far as to quote a letter of Adad-šumu-ușur, ${ }^{24}$ a well-known chief exorcist, in which he consoles the grieving king, most likely Esarhaddon, after the loss of a royal child:

\section{lū ša pațāri šs mišil màtīka lū taddin lū tapturašši}

Had it been curable, you would have given away half of your kingdom to have it cured! SAA 10 187: 10-12.

Or a letter of Iddin-Aššur to the king: ${ }^{25}$

annurig rēšāti ša mātīka hamussu ša Barhalzi memmēni lā nașṣa

As of now, no one is bringing in the first fruits of your land or the one-fifth tax from Barhalzi SAA 13 31: 4-7.

In $S A A 1968$, the use of the second person singular suffix may have one of these two possible reasons: (1) as with Adad-šumu-uṣur, the singular "you" emphasizes the intimacy of the sender/author with the king, or, (2) an alternative way is to take the conquest as a divine deed or intervention that changes the status of the land into the ruler's land, i.e., "your land". If the latter interpretation is correct, Šamaš-ila'i’s usage resembles that of Iddin-Aššur. In his letter, Iddin-Aššur, who may have been a priest or temple administrator, seems to use the authority of the god Aššur to justify his straight talk to the king when he collects taxes for the Aššur temple. Generally speaking, this type of usage is typical of letters from scholars, priests and the administrative personnel of Mesopotamian temples to the kings Esarhaddon and Assurbanipal, and

name broken away; see below for this letter), and 169: 3 (by Ah-abi, although the reading of his name, written as $\left({ }^{\mathrm{m}}\right) \mathrm{PAB}-b a$, is not entirely certain).

22. For example, see the phrase in the letters of Ašipâ ( $S A A 5$ 21-25, 27-30), Mannu-ki-Ninua (SAA 15 90, 94, 98, 100-101), Nabû-belu-ka"in (SAA 15 85-86, 88), Nashur-Bel (SAA 5 1-3, 6, 11, 14-15, 17-18) and Ša-Aššur-dubbu, (SAA 5 31-35, 37).

23. For attestations in the introductory formula, see $S A A 17$ 101: 5; 108: 7; 111: 5; 113: 6; 114: 6; 116: 7; 117: 8; 118: 7. For occurrences outside the introductory formula, see $S A A 5$ 52: 16; 79: 5, r.11 (on this letter, see below); 108 r.18; 118: 7; SAA 15 69: 18; 128 r.5; SAA 17 120: 22, r.1, 24, 26; SAA 18 199: 7; SAA 19 89: 23; 167: 7’.

24. It is not entirely certain that the letter was written by Adad-šumu-ușur; Marduk-šakin-šumi is an alternative. See the discussion in Parpola 1983: 160.

25. The $S A A$ edition reads the name of the author as Nadin-Aššur; compare, however, Postgate 1974: 280 and PNA 2/I, p. 504 s.v. Iddin-Aššur no. 6. It is not certain whether this letter was sent to Sargon II (see $S A A 13$, p. 34, note to no. 31) or to a later, seventh century king (see the above PNA entry), e.g., Esarhaddon or Assurbanipal. 
we do have many such letters available from the seventh century BC, but in comparison, only a handful of them are preserved from the eighth century. Of course the above-mentioned two reasons are not mutually exclusive, and may be in play simultaneously.

In $S A A 19$ 68, moreover, the invocation of Aššur and Šamaš is exceptional and may imply a preceding military activity in the area similar to that attested in another letter unearthed in Nimrud that concerns the planned attack on the Urarțian capital Țurušpâ. ${ }^{26}$ Although the blessing formula invoking the gods Aššur and Šamaš is extremely rare among the extant NeoAssyrian letter corpus, ${ }^{27}$ in this case it appears impossible to find out the geographical origin of the letter by means of the blessing formula alone: my assumption is that the letter was written in 739 in the aftermath of a military campaign to Ulluba. A military context could be a specific motive for substantiating the invocation of Aššur and Šamaš to bless the king in the letter. ${ }^{28}$ Furthermore, $S A A 1965,{ }^{29}$ a letter sent by the chief cupbearer Nabû-e[tiranni], must relate to the same event in 739 because it mentions the "deported" Ullubeans who are at the disposal of Inurta-ila'i, governor of Nasibina. Hence $S A A 1965$ seems to importantly prove that among the extant Nimrud Letters there is at least one letter that directly relates to the campaign of $739 .{ }^{30}$

\section{Identifying the Governors of Halzi-atbari}

Šamaš-ila'i, the name of the author or sender of the letter $S A A 19$ 68, was relatively common in Assyria. It is attested altogether at least thirty-six times in the Neo-Assyrian Text Corpus Project's database. ${ }^{31}$ From these attestations, a passage in a letter of Aššur-belu-da'in, probably the governor of Halzi-atbari (see below), may contain the key to the identitification of our Šamaš-ila’i:

ušhāya qudāya . . . àlāni ša ūmāti ša Šamaš-ila’i la hanšūni ūmâ annurig ša-qurbūte uptahhir ina muhhīya nașsa

The Ušhaeans and Qudaeans . . . towns which were not submissive in the days of Šamaš-ila’i, the royal bodyguard has now assembled and brought over to me SAA 5 78: 4-15.

26. SAA 19 76: 5-6. See also, e.g., SAA 8 418: 4-5; this report refers to the conquest of Kush and Egypt, and this section begins with "Aššur, Šamaš, Nabû, and Marduk . ..."

27. The only other examples of Neo-Assyrian letters which invoke A ̌̌šur and Šamaš (and no other gods) are KAV 214, VAT 9770 (both letters by Nabû-ahhe-eriba, from Assur, to his lord Didia), SAA 16 41 (by Nabû-tukulti, Nabû-šumu-lešir and Mutakkil-Adad), SAA 1359 (by Urdu-Nabû from Kalhu) and CTN 2180 (sent by Hunanu, possibly from Kalhu). Only the last example dates to the eighth century (cf. Luukko 2012: 105, n. 44); the other examples were all written in the seventh century. The mention of Samaš in the blessing formula hardly indicates a ritual connection (cf. note 7).

28. As an alternative hypothesis, the possibility should not be excluded that Šamaš-ila’i is writing to the campaigning king from the Assyrian capital or from another city in Assyria. If this interpretation proves correct, then there are of course obvious difficulties with identifying Šamaš-ila'i’s as governor of Halzi-atbari.

29. ND 2434.

30. See also $S A A 19$, pp. xxi (Table II, letter no. 74) and xlii.

31. All these attestations are treated in PNA 3/II, p. 1200-1201; there may be as many as twentyeight individuals with this name, although this seems unlikely. 
The passage $S A A 5$ 78: 4-15 was not commented on in SAA 5. However, on p. 245 s.v. Šamašila'i in the volume's "Index of Personal Names", Šamaš-ila'i is referred to as "(eponym 818)". ${ }^{32}$ As for the person mentioned in $S A A 578$, this identity is not impossible, although perhaps far-fetched as it hardly makes good sense to mention a 100-year-old eponym holder. Therefore, the reference to Šamaš-ila'i in SAA 578 may be explained in another, much simpler way: Aššurbelu-da" in is most likely referring to his predecessor, an earlier governor of Halzi-atbari. ${ }^{33}$

As for lines 11-12 of the letter, Neo-Assyrian officials sometimes spoke about their immediate predecessors by using the phrase (̌́a/ina) ümāti ̌̌ $a$ PN, "at the time of PN", and this expression occurs elsewhere in Neo-Assyrian and Neo-Babylonian sources, referring to the predecessor of the current office holder. ${ }^{34}$ An alternative way to say the same is to employ the structure ina (ana/ištu) tarși PN, "at the time of", but the latter is almost exclusively used to refer to rulers in the sense "in the reign of". ${ }^{35}$ However, a fragmentary Babylonian letter to the king of Assyria may have combined the two phrases:

ana tarși [UD].MEŠ ša ̌̌ulâ

During [the day]s of Šulâ, ... SAA 18 102: 15'-16'.

The same Šamaš-ila'i, thus presumably the first governor of Halzi-atbari, may also occur in several horse lists, ${ }^{36}$ or be mentioned in another letter, two administrative documents and in a legal transaction. ${ }^{37}$ In practice, however, there is no way of ascertaining with certainty the identities of these people because of the high frequency of the name and the possible distance in time between these attestations. Also, it is possible that another Nimrud Letter was written by the same Šamaš-ila'i as $S A A 19$ 68: SAA $1969,{ }^{38}$ possibly sent to Tiglath-pileser III, could have originated from him.

In the greeting formula of this letter, the sender exceptionally states that both the provinces of the treasurer and chief cupbearer are well, but unfortunately the authorship of the letter remains uncertain. ${ }^{39}$ In any case, the sender of this letter may have functioned as an intermediary between the treasurer and chief cupbearer. Moreover, the sender may have also been connected to the palace herald since he writes to the king that he "is performing the works

32. This official served under Šamši-Adad V. Although his title is not preserved in extant eponym lists (Millard 1994: 31), he may have been treasurer, assuming that the traditional order of eponyms was followed at the time.

33. This possibility is also considered in PNA 3/II, p. 1201, s.v. Šamaš-ila’i no. 8.

34. See, e.g., SAA 10 364: 4' (addressed to Esarhaddon), SAA 17 95: 4'-12', SAA 18 185: 7. The passage in $S A A 18186$ r.8e-9e also refers to the past, but not to Nabû-ušallim's (sender/author of the letter) predecessors.

35. See, e.g., Millard 1994: 71, RIMA 3 A.0.103.1 i 39, and passim in Assyrian royal inscriptions, as well as in other genres of Neo-Assyrian texts.

36. See CTN 3, pp. 142, 175 (note to line iii.23), 182, but cf. PNA 3/II, pp. 1201-202, s.v. Šamaš-ila’i nos. 3 and 5 .

37. SAA 1 193: 2'; SAA 637 r.12; SAA 1132 r.3, 125 r.4-5. Cf. PNA 3/II, pp. 1201-202, s.v. Šamašila'i nos. $9,13,3$ and 27$)$.

38. ND 2798. The letter is discussed in, e.g., Mattila 2000: 51 (= NL 55).

39. See the critical apparatus of letter no. 69 in $S A A$ 19. The original tablets of $S A A 1968$ and 69 cannot be properly compared since no. 69 is in the British Museum (London), while no. 68 is probably in the Iraq Museum (Baghdad). 
of Šarru-iqbi about which the king commanded me". ${ }^{40}$ Šarru-iqbi is an Assyrian fortress on the Mannean border in the east. Althought its exact location is uncertain, it is possible that Šarruiqbi was not very far from the area controlled by the palace herald. The introductory formula of SAA 1969 may indicate that the sender would have travelled to the east through the provinces of treasurer and chief cupbearer, and possibly partly through the province of the palace herald.

Aššur-belu-da"in, most likely the second governor of Halzi-atbari, is the sender of three Neo-Assyrian letters to Sargon II (SAA 5 78-80), all of which date to ca. $710 .{ }^{41}$ Of these three letters, SAA 578 (quoted above) is most promising because it includes three ethnic names - the Mumaeans, Ušhaeans and Qudaeans - that could help us pin down the geographic location of Halzi-atbari. Unfortunately, apart from this letter nothing is known about the "unsubmissive Mumaeans" (r.11) since the place name Mumu does not appear elsewhere in extant NeoAssyrian sources. With regard to the Ušhaeans and Qudaeans, the letter states that they submitted to the king's treaty. Apart from $S A A 5$ 78, Quda and Ušhu are both only known from one other source: Quda ${ }^{42}$ is one of the many "cities" named by Tiglath-pileser III in accounts of his eleventh campaign in 735, which was directed against Urartu (RINAP 1, no. 18: 4-5); and, if we believe an inscription of Assurnașirpal, ${ }^{43}$ Ušhu must have been situated close to the foot of Mount Nipur or Mount Pasate. ${ }^{44}$ All three ethnic groups might have been "peripheral" Halziatbareans. However, the potential weakness of this argument lies at the end of the quotation "the royal bodyguard has now assembled (the Ušhaeans and Qudaeans) and brought (them) over to me" (lines 14-15) since this passage could refer to deported people. If that proves to be the case, then the Ušhaeans and Qudaeans mentioned in SAA 578 were not Halzi-atbareans. In addition, and more importantly, SAA 578 says that "the whole mountain (area) has observed the king's tr[eaty]" (r.4-5).

On the other hand, Yasumu (modern Karacadač) and Bit-Zamani presumably occur in SAA 579 r.5-6 as the intermediate stage of the deported Chaldeans. These places are much further in the north-west than the place where Aššur-belu-da"in was stationed. Whether Yasumu and Bit-Zamani were also destinations of refugees from Halzi-atbari, of whom it is said that they have "run away in great numbers and are (scattered) all over the mountains" (lines 10-12), is less clear from $S A A 579$. The deported Chaldeans mentioned in $S A A 579$ also appear in the fragmentarily preserved $S A A 580$, in which they are said to be building their houses $\left(\mathrm{r} .3^{\prime}-4^{\prime}\right)$, apparently in Halzi-atbari. ${ }^{45}$

40. SAA 19 69: 8-9.

41. See Fales 1983: 70, 142-43. According to PNA 1/I, p. 172, he was a "high official, perhaps the governor of Halzi-atbar". Most of Sargon's letters from Nineveh date to the last five years of his rule; see, e.g., Radner 2014: 82.

42. The mention of URU.qu-ta in RINAP 1 39: 32 may refer to another "city" in the north-west (but cf. Fuchs 2003: 53*, n. 29), whereas a URU.qu-ut-ta in the vicinity of Waisi, in the north-east, was burnt by Sargon II according to the account of his famous eighth campaign (TCL 3, line 304).

43. RIMA 2 A.0.101.1 i 71.

44. See Liverani 1992: 29 and Parker 2001: 47.

45. A short summary of these two letters, especially of no. 79, is given in Gallagher 1994: 62, 64-65. Another fragmentary letter, $S A A 5$ 14, titled "Chaldeans in Bit-Zamani", may pertain to the same events. Note also the remark in $S A A$ 5, p. 11, the critical apparatus to no. 14: 7: "A date after 710 is implied by r. 4, which can only refer to Chaldeans deported and resettled in the north after the defeat of Merodach-baladan." 
Šulmu-šarri, governor of Halzi-atbari and eponym of the year 698, dates various texts as eponym. ${ }^{46}$ Unfortunately, nothing else is known about this high official who served under Sennacherib. It is worth noting, however, that he is the only governor of Halzi-atbari attested as eponym. Moreover, it is certain in Šulmu-šarri's case that he was the governor of the province under discussion.

Šulmu-šarri's eponymate is followed by a gap of about thirty or even fifty years, after which we can read the following in an administrative document from Nineveh, originating from the reign of Assurbanipal, ${ }^{47}$ and edited by Fales and Postgate: [" ${ }^{\mathrm{m}}$ it-ri-ia LÚ.EN.N[AM] /

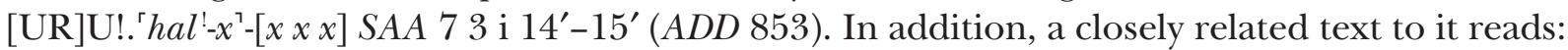
${ }^{\mathrm{m}} a$-tar-a-a LÚ.NAM KUR. $\llbracket x x \rrbracket S A A 74$ i 12' (ADD 854), ${ }^{48}$ but whilst in SAA 73 the partial restoration ${ }^{\ulcorner\mathrm{m} !}$ ' it-ri-ia LÚ.EN.N[AM] / [UR]U!' 'hal'-z[i'-AD.BAR] "Itriya, governor[or of] Halz[iatbari]" appears justifiable, in the second tablet it is impossible to accommodate four signs, i.e., the shortest attested writing of the province is hal-zi-AD.BAR, when it only has two erased signs at the end of the line (I collated the two passages in June 2014). Therefore, we cannot convincingly restore "Ataraya, governor of [Halzi-atbari]" in $S A A 74 \mathrm{i} \mathrm{12'.} \mathrm{In} \mathrm{any} \mathrm{case,} \mathrm{one} \mathrm{might} \mathrm{sug-}$ gest that the assonance between the names Halzi-atbari and Barhalzi/a (SAA 73 i 13' and 4 i 11'; cf. $S A A 10$ 96: 17-19 where other place names are inserted between the two toponyms) could explain why these provinces were apparently presented consecutively in the two administrative documents. The spellings Itriya and Ataraya may be expounded as two variant forms of the personal name Idraya ${ }^{49}$ the last governor of the province for whom we have these two pieces of evidence, however questionable they may seem.

\section{On Halzi-atbari's Location}

As already mentioned at the beginning of this paper, extant Neo-Assyrian sources are not informative enough to ascertain the exact location of Halzi-atbari; too many questions remain unanswered. Rather than committing myself to any theory about the province's location, I would like to briefly discuss some details that may both help and complicate our endeavour to locate Halzi-atbari.

First, the geographic relation between Halzi-atbari and Ulluba appears unclear to me: are they close together or far apart from? Tiglath-pileser's fragmentary Mila Mergi inscription, which deals with both lands, does not give a clear answer to this, although that text seems to imply that Halzi-atbari was along the route from Assyria to Ulluba. What we do not know is the direction from which Tiglath-pileser approached Ulluba. The Assyrian army could have marched on it from either the south, east or west. Second, the fragmentary passage in SAA 5 98: 4-9, a letter written by Aššur-reșuwa, ${ }^{50}$ who was also in contact with the treasurer, ${ }^{51}$ may support the

46. The references to this official are presented in PNA 3/II, p. 1278 s.v. Šulmu-šarri no. 9.

47. On the approximate date of SAA 73 and 4, see Mattila 2000: 17.

48. These two entries are presumed to refer to the same person; see the note to line i.14 in $S A A 7$, p. 6. On the reading of Halzi-atbari in $S A A 73$ i 15' see also Radner 2006: 54.

49. As done in PNA 2/I, p. 505, s.v. Idrāia or Idrïja or Idrì-Aya no. 4.

50. On the important role and activities of Aššr-reșuwa on the Assyrian-Urarțian border in Kumme, see PNA 1/I, pp. 212-13, s.v. Aššūr-rēșūwa no. 2 and Radner 2014: 86-88, 90-92.

51. SAA 5 96-97. For a discussion, see Radner 2014: 87. 
proximity of Halzi-atbari to Kumme. In addition, the Assyrian eponym chronicle records that the campaign of 736 was directed towards the foot of Mount Nal; no report of this campaign is preserved in an official royal inscription, apart from a couple of fragmentary lines. ${ }^{52}$

On the other hand, what is known about the Neo-Assyrian use of basalt favours a more western location of Halzi-atbari, possibly in eastern Syria or Turkey. For instance, Moorey repeatedly stressed that the basalt used in Assyria came from Syria and Turkey, ${ }^{53}$ although it was also abundantly available in the north: "It [basalt] could also be obtained around Cizre in the upper Tigris valley." ${ }^{54}$ The letter $S A A 581^{55}$ might report on areas west of the Assyrian heartland; the letter implies a legal case against an unnamed governor of Halzi-atbari, who claims the Ehimaneans ${ }^{56}$ as his servants. The author or sender of that letter, Aššur-zeru-ibni, ${ }^{57}$ might be identified as Zeru-ibni, governor of Rașappa and eponym of the year 718, but that governor of Rașappa is known from other Neo-Assyrian sources only as Zeru-ibni, although it may be a shortened form of his name. ${ }^{58}$ The recipient of the letter is a man named Nergal-etir, Aššurzeru-ibni's "brother", possibly the same high official who was active on Assyria's eastern border during the reign of Sargon II. ${ }^{59}$ These identifications are mere guesses and, even if we were able to find out the titles of these two officials, this letter contains other problems. For example, although Radner (1997: 24) has convincingly located Ehiman in the upper Khabur region, it is uncertain whether or not the Ehimaneans in the letter were deportees and, therefore, the

52. For a discussion of this state of affairs and an edition of these lines, see RINAP 1, pp. 6, 7, 13, 17 and 54.

53. E.g., in Moorey ${ }^{2} 1999:$ 21, 24, 30, 336, 340; see also Reade 2008: 17. On the use of basalt in Assyria, see Moorey ${ }^{2} 1999: 341-45$.

54. Moorey ${ }^{2}$ 1999: 336; see also ibid. 22, 345, Reade 1981: 154-55 and Reade 2008: 22: "Basalt was readily available some distance upstream on the Tigris, in modern Turkey, and was commonly used in Assyria for special purposes, such as the manufacture of grinding stones. It was also used for door-sockets and column-bases, and for various other purposes from time to time."

55. SAA 581 and SAA 5100 are the only Neo-Assyrian letters in the collections of the Louvre, but it is puzzling that they have ended up in two separate collections there; their respective museum numbers are AO 4506 and N III 3158. This seems to suggest that they were two separate sporadic finds, with no connection to one another. I do not know what the evidence is that makes Radner (2014: 82) state that "Even more importantly, two letters [SAA 581 and 100] from Sargon's correspondence were excavated in his palace at Dur-Šarruken.” This is certainly the most likely scenario for these two letters, but are Botta's and Victor Place's nineteenth-century excavations at Nineveh to be written off as an alternative? Both the letters are thus apparently from the reign of Sargon II, but without a firm find spot this may not be easily proven with $S A A 581$. In any case, that letter might relate to the north, just like $S A A 5100$. Note, however, that these two pieces of correspondence have one important difference: SAA 5100 is about Kummean smugglers and sent to the king, while $S A A 581$ was addressed to Nergal-etir. It is not impossible that the latter ended up at the court via the hands of the chief eunuch (see lines 7,15 of the letter).

56. The reading of the name of this ethnic group is not entirely certain; see the discussion in Radner 1997: 24.

57. Accidentally read Aššur-zeru-iddina in SAA 5, but cf. Contenau 1926: 3, Radner 1997: 23 and PNA 1/I, p. 228, s.v. Ǎšūr-zēru-ibni no. 1. Radner (2001: 275 n. 55) suggests he is an official of a neighbouring province to the governor of Halzi-atbari.

58. See PNA 3/II, p. 1443, s.v. Zēru-ibni no. 3.

59. Nergal-etir, probably also governor, is the sender of SAA 15 65-68 and BM 30205 (see Van Buylaere in this volume). 
Ehimaneans might appear beyond their normal dwellings, e.g., working at Dur-Šarruken, where many provincial governors were involved in building Sargon's new capital. Thus, the letter may present the two corresponding officials outside their normal surroundings, that is, out of their usual, expected context.

\section{Conclusions}

After Tiglath-pileser III's seventh campaign to Ulluba in 739, the governor of Halzi-atbari was presumably a man called Šamaš-ila'i. He was probably followed in the office by Aššur-beluda"in. Although there is no direct evidence, it seems highly likely that Šamaš-ila'i and Aššurbelu-da"in were the successive governors of the same province. How can we be sure that the province is Halzi-atbari? I do not think we can know for certain, and it would be foolhardy to insist that this was the case, although SAA 579 provides important information on some runaway Halzi-atbareans. These runaways fit well with the general situation of a recently annexed province (739) in a mountainous area: the local men wanted to keep their freedom and were ready to risk their lives for it.

Aššur-belu-da"in may have been succeeded by Šulmu-šarri, eponym of the year 698. Idraya may be the name of the last governor of Halzi-atbari for whom we have some - if not totally convincing - evidence. If correctly interpreted, altogether the above discussed four governors of Halzi-atbari might span a period of seventy to ninety years, from 739 until ca. 670 or 650 BC. It would not be surprising if that province had had more than four governors during this period.

The tentative identification of governors of Halzi-atbari may be presented in a tabular form as follows:

Table I. The governors of Halzi-atbari

\begin{tabular}{|l|}
\hline Šamaš-ila’i, in the reign of Tiglath-pileser III (since 739). \\
\hline Aššur-belu-da')in, late in the reign of Sargon II. \\
\hline Šulmu-šarri, eponym of the year 698 under Sennacherib. \\
\hline Idraya, reign of Assurbanipal. \\
\hline
\end{tabular}

With present knowledge, the location of Halzi-atbari either in the area of Jebel Sinjar or to the south, west or east of Ulluba should not be ruled out since one may present circumstantial evidence in support of each of these regions. At the moment a subtle analysis on the province's location is hindered by elusive details. Hence new and more explicit evidence is needed since without it the location of the province remains debatable. In addition to the fact that the highest officials had landholdings in various parts of the Assyrian empire, with many subordinates, the interpretive problems surrounding peoples and their geographical location arise from the military campaigns, deportations resulting from them, and the compulsory participation of these high officials in large construction works. All these interpretive problems are easy to detect when studying Neo-Assyrian sources. 
But as to the report of Tiglath-pileser's seventh campaign at Mila Mergi, its wording, "Halziatbari, a rebellious land", may suggest a detour on the road to Ulluba. On the other hand, one might go a step further and ask: would it be unthinkable to consider the land of Ulluba as part of a larger entity, the land/province of Halzi-atbari? ${ }^{60}$ Alternatively, Halzi-atbari may have been a small province in the proximity of Ulluba.

60. Unfortunately the text of the Mila Mergi inscription is broken after the mention of Halzi-atbari, but it appears between the sections about Ulluba. Radner 2006: 44 (Karte 1, no. 40), 56-57 situates the province of Birtu, allegedly the same as the former Ulluba as the Assyrians no longer used the name Ulluba after Tiglath-pileser's reign, more or less where Parpola and Porter locate Halzi-atbari on their map (see note 6, above). At least SAA 10 96: 19-20 makes it clear that Birtu and Halzi-atbari are two separate provinces. As for Birtu, its exact location is still uncertain but see, e.g., Parpola 1983: 318. Related to Birtu and Ulluba, there is also a problem that concerns the city of Aššr-iqiša. It only appears in the inscriptions of Tiglath-pileser III, according to which he built the city as a provincial capital of Ulluba (RINAP 1, nos. 39: 28-29 and 41: 30'-31'; cf. also ibid. no. 49: $9^{\prime}-10^{\prime}$ ). What happened to Aššur-iqiša after Tiglath-pileser's reign? Should we assume that its name was changed to Birtu or that the location of the provincial capital was moved, or is it only a matter of time before evidence for Aššur-iqiša after Tiglath-pileser's rule turns up?

\section{References}

Abusch, T., and Schwemer, D.

2011 Corpus of Mesopotamian Anti-Witchcraft Rituals, vol. 1. AMD 8/1. Leiden: Brill.

Cole, S. W., and Machinist, P.

1998 Letters from Priests to the Kings Esarhaddon and Assurbanipal. SAA 13. Helsinki: Helsinki University Press.

Contenau, G.

1926 Contrats et lettres d'Assyrie et de Babylonie. TCL 9. Paris: Geuthner.

Dalley, S., and Postgate, J. N.

1984 The Tablets from Fort Shalmaneser. CTN 3. London: British School of Archaeology in Iraq.

Dietrich, M.

2003 The Babylonian Correspondence of Sargon and Sennacherib. SAA 17. Helsinki: Helsinki University Press.

Faist, B.

2007 Alltagstexte aus neuassyrischen Archiven und Bibliotheken der Stadt Assur. StAT 3. Wiesbaden: Harrassowitz.

Fales, F. M.

1983 Cento lettere neo-assire. Traslitterazione e traduzione, commento e note. Venice: Quaderni nel seminario di iranistica, uralo-altaistica e caucasologia dell'università degli studi di Venezia.

Fales, F. M., and Postgate, J. N.

1992 Imperial Administrative Records, Part I. Palace and Temple Administration. SAA 7. Helsinki: Helsinki University Press.

1995 Imperial Administrative Records, Part II. SAA 11. Helsinki: Helsinki University Press.

Fuchs, A.

2003 Ein Inschriftenfragment Tiglatpilesers III. Eretz-Israel 27: 49*-54*.

Fuchs, A., and Parpola, S.

2001 The Correspondence of Sargon II, Part III. Letters from Babylonia and the Eastern Provinces. SAA 15. Helsinki: Helsinki University Press. 
Gallagher, W. R.

1994 Assyrian Deportation Propaganda. $S A A B$ 8: 57-65.

Grayson, A. K.

1991 Assyrian Rulers of the Early First Millennium B.C. Volume I (1114-859 B.C.). RIMA 2. Toronto: University of Toronto Press.

1996 Assyrian Rulers of the Early First Millennium B.C. Volume II (858-745 B.C.). RIMA 3. Toronto: University of Toronto Press.

Hunger, $\mathrm{H}$.

1992 Astrological Reports to Assyrian Kings. SAA 8. Helsinki: Helsinki University Press.

Johns, C. H. W.

1898-1923 Assyrian Deeds and Documents, I-IV. Cambridge: Deighton, Bell and Co.

Lanfranchi, G. B., and Parpola, S.

1990 The Correspondence of Sargon II, Part II. Letters from the Northern and Northeastern Provinces. SAA 5. Helsinki: Helsinki University Press.

Liverani, M.

1992 Studies on the Annals of Ashurnasirpal II. 2: Topographical Analysis. QGS 4. Rome: Università di Roma "La Sapienza", Dipartimento di Scienze storiche, archeologiche e antropologiche dell'Antichità.

Luukko, M.

2004 Grammatical Variation in Neo-Assyrian. SAAS 16. Helsinki: The Neo-Assyrian Text Corpus Project.

2012 On Standardisation and Variation in the Introductory Formulae of Neo-Assyrian Letters. Iraq 74: $97-115$.

2013 The Correspondence of Tiglath-pileser III and Sargon II from Calah/Nimrud. SAA 19. Helsinki: The Neo-Assyrian Text Corpus Project.

Luukko, M., and Van Buylaere, G.

2002 The Political Correspondence of Esarhaddon. SAA 16. Helsinki: Helsinki University Press.

Mattila, R.

2000 The King's Magnates. A Study of the Highest Officials of the Neo-Assyrian Empire. SAAS 11. Helsinki: The Neo-Assyrian Text Corpus Project.

2002 Legal Transactions of the Royal Court of Nineveh, Part II. Assurbanipal through Sin-šarru-iškun. SAA 14. Helsinki: Helsinki University Press.

Millard, A. R.

1994 The Eponyms of the Assyrian Empire 910-612 BC. SAAS 2. Helsinki: The Neo-Assyrian Text Corpus Project.

Moorey, P. R. S.

1999 Ancient Mesopotamian Materials and Industries: The Archaeological Evidence. Winona Lake, IN: Eisenbrauns.

Parker, B. J.

2001 The Mechanics of Empire: The Northern Frontier of Assyria as a Case Study in Imperial Dynamics. Helsinki: The Neo-Assyrian Text Corpus Project.

Parpola, S.

1983 Letters from Assyrian Scholars to the Kings Esarhaddon and Assurbanipal, Part II: Commentary and Appendices. AOAT 5/2. Kevelaer: Butzon \& Bercker; Neukirchen-Vluyn: Neukirchener Verlag des Erziehungsvereins.

1987 The Correspondence of Sargon II, Part I. Letters from Assyria and the West. SAA 1. Helsinki: Helsinki University Press.

1993 Letters from Assyrian and Babylonian Scholars. SAA 10. Helsinki: Helsinki University Press. 
Parpola, S., and Porter, M.

2001 The Helsinki Atlas of the Near East in the Neo-Assyrian Period. Helsinki: The Casco Bay Assyriological Institute and the Neo-Assyrian Text Corpus Project.

Postgate, J. N.

1973a The Governor's Palace Archive. CTN 2. London: British School of Archaeology in Iraq.

1973b The Inscription of Tiglath-Pileser III at Mila Mergi. Sumer 29: 47-59.

1974 Taxation and Conscription in the Assyrian Empire. StPohl SM 3. Rome: Biblical Institute Press.

1995 Assyria: the Home Provinces. Pp. 1-17 in Neo-Assyrian Geography, ed. M. Liverani. QGS 5.

Rome: Università di Roma "La Sapienza”, Dipartimento di Scienze storiche, archeologiche e antropologiche dell'Antichità.

Radner, K.

1997 Erntearbeiter und Wein. Neuassyrische Urkunden und Briefe im Louvre. SAAB 11: 3-29.

2001 The Neo-Assyrian Period. Pp. 265-88 in Security for Debt in Ancient Near Eastern Law, ed. R. Westbrook and R. Jasnow. Leiden: Brill.

2006 Provinz. C. Assyrien. RlA 11/1-2: 42-68.

2014 An Imperial Communication Network: The State Correspondence of the Neo-Assyrian Empire. Pp. 64-93, 222-26 in State Correspondence in the Ancient World: From New Kingdom Egypt to the Roman Empire, ed. K. Radner. Oxford and New York: Oxford University Press.

Radner, K., and Baker, H. D. (eds.)

1998-2011 The Prosopography of the Neo-Assyrian Empire. Helsinki: The Neo-Assyrian Text Corpus Project.

Reade, J. E.

1981 Fragments of Assyrian Monuments. Iraq 43: 145-56.

2008 Real and Imagined "Hittite Palaces" at Khorsabad and Elsewhere. Iraq 70: 13-40.

Reynolds, F.

2003 The Babylonian Correspondence of Esarhaddon and Letters to Assurbanipal and Sin-šarru-iškun from Northern and Central Babylonia. SAA 18. Helsinki: Helsinki University Press.

Saggs, H. W. F.

2001 The Nimrud Letters, 1952. CTN 5. London: British School of Archaeology in Iraq.

Schroeder, O.

1920 Keilschriftexte aus Assur verschiedenen Inhalts. WVDOG 35. Leipzig: Hinrichs.

Tadmor, H.

1994 The Inscriptions of Tiglath-pileser III, King of Assyria. Jerusalem: Israel Academy of Sciences and Humanities.

Tadmor, H., and Yamada, S.

2011 The Royal Inscriptions of Tiglath-Pileser III (744-727 BC) and Shalmaneser V (726-722 BC), Kings of Assyria. RINAP 1. Winona Lake, IN: Eisenbrauns. 